\title{
The impact of growth regulators on grape varieties in the Urals
}

\author{
M.A. Tikhonova ${ }^{*}, A . A$. Mushinskiy, and E.V. Aminova \\ Orenburg branch of FSBSI FSC of Gardening, 460041, Orenburg, Nezhenskoe highway 10, Russia
}

\begin{abstract}
The article presents data on the effectiveness of the use of drugs on the structural components of the productivity of grape varieties. Research objects of growth regulators are Zircon and Mival Agro. Tests were carried out on table grape varieties Arkadia and Kodryanka. The same cultivars without treatment served as control. In the experiment with the use of Mival Agro the maximum indicator of the average bunch weight of the Arkadia variety was higher by $28.0 \%$ in comparison with the control, for the Kodryanka variety the indicator increased by $30.2 \%$. In terms of productivity in the bush in the Arkadia variety the increase was $70.8 \%$, in the Kodryanka grape variety it was $77.5 \%$ higher than the control variant when exposed to a similar preparation. Processing of experimental bushes in the variant Mival Agro showed the maximum increase in yield per hectare in the variety Arkadia by $70.0 \%$, in the variety Kodryanka by $78.1 \%$ in comparison with the control option. Growth regulators have a positive effect on the productivity and yield of grape varieties, the most significant indicators are in the variants of the experiment with the use of the drug Mival - Agro.
\end{abstract}

\section{Introduction}

Grapes are the main product of the food and wine industry [1-3].

For the successful implementation of the task of grape production, it is necessary to increase productivity, not only by expanding their areas, but by increasing the yield per unit area. In this regard, it is necessary to improve the technology of grape production and introduce the achievements of science into practice. One of the effective methods aimed at increasing the yield and improving the quality of grape products is the use on a scientific basis of physiologically active substances, which include growth regulators [4 - 8].

The condition for the vital activity of the grape culture, its growth, development and fruiting is the provision of conditions for its optimal nutrition, which reduces the negative influence of agroecological factors, as well as the selection of varieties that are resistant to these factors. An important tool for reducing the negative impact of these factors can be the use of growth regulators [9 - 11].

Growth regulators have a beneficial effect on the processes occurring in the grape plant, on carbohydrate and nitrogen metabolism, enzymes are activated, the amount of chlorophyll in the leaves increases, the intensity of photosynthesis increases, the yield and sugar content

\footnotetext{
* Corresponding author: marintikhonova@yandex.ru
} 
of berries is increased, the shedding of flowers and ovaries is reduced, the ripening of shoots is improved, the grape plant becomes more resistant to diseases and unfavorable environmental conditions [12 - 15].

The purpose of the research is to evaluate the effectiveness of the impact of growth regulators on the constituent components of the productivity of table grapes varieties in the Urals.

\section{Objects and methods of research}

Studies on the effect of growth regulators on grape varieties were carried out at the Orenburg branch of the Federal State Budgetary Scientific Institution of the Federal Research Center of Horticulture, in 2018-2020 on the collection plot of grapes, the planting scheme is $3 \mathrm{x}$ $1.5 \mathrm{~m}, 2012$ setting with a density of 2200 plants / ha. Grapes are a covering culture, the formation of the bushes is fan-shaped, without a standard load on a bush 40 pieces of eyes on a bush. The objects of research were plant growth regulators Zircon (a mixture of hydroxycinnamic acids), Mival Agro (760 g / $\mathrm{kg}$ of orthoresoxyacetic acid triethanolammonium salt $+190 \mathrm{~g} / \mathrm{kg}$ 1-chloromethylsilatrane, tests were carried out on introduced grape varieties Arkadia and Kodryanka, the same varieties served as control without treatment. Timing of treatments: before flowering grapes, 10 days after flowering grapes, during the formation of berries. For treatment was used a knapsack sprayer pump "Verve." The experiment was repeated 3 times, 5 plants in each variant. The consumption rate of drugs was according to the instructions. Field experiments, records, observations were carried out according to generally accepted methods [16-18]. Statistical data processing was carried out according to B.A. Dospekhov [19].

\section{Discussion of research results}

In our studies we determined the effect of plant growth regulators on the structural components of productivity of grape varieties Arkadia and Kodryanka. The results of the studies have shown that the use of the drugs contributes to an increase in the productivity index of grape plants.

Under the conditions of an equal load in the experimental variants, shoots were developed on average in the Arkadia variety 12 pieces, in the Kodryanka variety 13 pieces. The fruitfulness of shoots on average for varieties was $75.0-84.6 \%$. In the variant of the experiment, varieties without treatment with an indicator of the coefficient of fruiting: Arkadia - 0.75, Kodryanka - 0.84 varieties were assigned to the group with average fruitfulness of shoots (0.8-0.6) [20]. With the use of the Zircon drug, the fruiting coefficient increased and was 0.91 in Arkadia and 1.07 in Kodryanka, the varieties are assigned to the group with high fruitfulness of shoots (1.1-0.9) [20]. The maximum indicators of the fruiting factor when using the drug Mival Agro on grape varieties with high fruitfulness of shoots were Arkadia - 1.0, Kodryanka - 1.15.

In the variants of the experiment of the Arkadia variety, the mass of the bunch varies from 353.4 to $452.6 \mathrm{~g}$, depending on the variant of the experiment under study (Table 1).

Table 1. The effect of growth regulators on the average weight of a bunch of the Arkadia variety.

\begin{tabular}{|c|c|c|c|}
\hline \multirow{2}{*}{ Experience options } & \multirow{2}{*}{$\mathrm{X}_{\mathrm{cf}, \mathrm{g}}$} & \multicolumn{2}{|c|}{ Deviation from control } \\
\cline { 3 - 4 } & & $\mathrm{g}$ & $\%$ \\
\hline Control & 353.4 & - & - \\
\hline
\end{tabular}




\begin{tabular}{|c|c|c|c|}
\hline Zircon & 391.4 & 38.0 & 10.7 \\
\hline Mival Agro & 452.6 & 99.2 & 28.0 \\
\hline NSR 05 & 11.8 & - & - \\
\hline
\end{tabular}

In the Zircon variant, the average bunch weight was $391.4 \mathrm{~g}$, in comparison with the control variant it increased by $10.7 \%$ (Fig. 1 ).

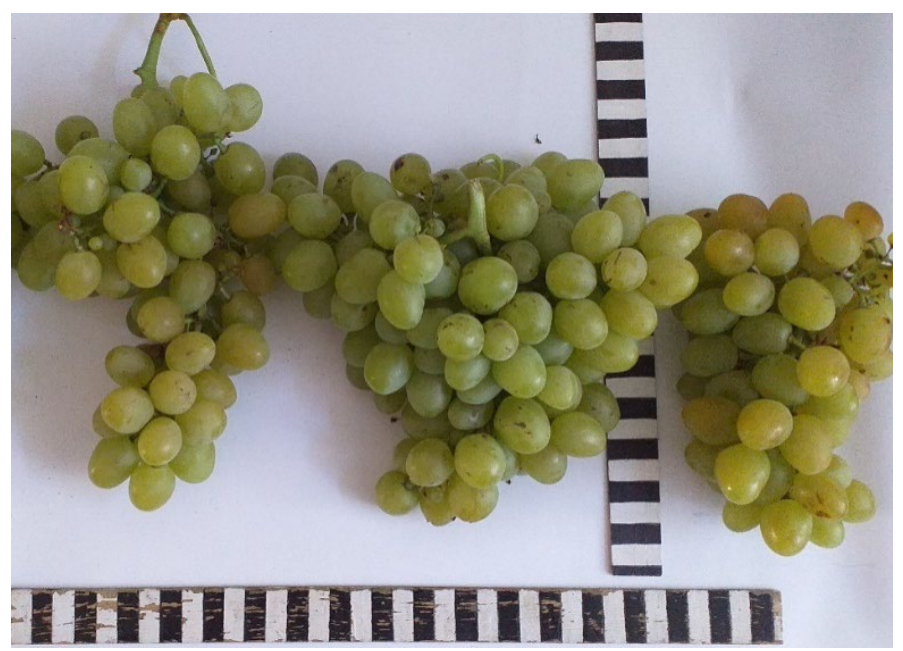

Fig.1. The effect of plant growth regulators on the size of a bunch of grapes of the Arkadia variety with the drug 1) Zircon; 2) Mival Agro; 3) Control without processing.

In the experiment with the drug Mival Agro, the maximum indicator of the average weight of the bunch was noted $-452.6 \mathrm{~g}$, the weight increased in comparison with the control by $28.0 \%$.

The bunch weight varies from 303.5 to $395.4 \mathrm{~g}$ in the variants of the experiment with the Kodryanka variety (Table 2).

Table 2. The effect of growth regulators on the average mass of a bunch of the Kodrianka variety.

\begin{tabular}{|c|c|c|c|}
\hline \multirow{2}{*}{ Experience options } & \multirow{2}{*}{$\mathrm{X}_{\mathrm{cf}, \mathrm{g}}$} & \multicolumn{2}{|c|}{ Deviation from control } \\
\cline { 3 - 4 } & & $\mathrm{g}$ & $\%$ \\
\hline Control & 303.5 & - & - \\
\hline Zircon & 349.2 & 45.7 & 15.1 \\
\hline Mival Agro & 395.4 & 91.5 & 30.2 \\
\hline NSR $_{05}$ & 12.7 & - & - \\
\hline
\end{tabular}

In the variant with the Zircon drug, the average weight of the bunch was $349.2 \mathrm{~g}$, in comparison with the control variant it increased by $15.1 \%$.

In the experiment with Mival Agro, the maximum indicator of the average mass of a bunch was noted $-395.4 \mathrm{~g}$, an increase of $30.2 \%$.

As can be seen from tables 1,2, the drugs promoted better formation of bunches of grape varieties, intensified growth and contributed to an increase in the size of berries and allowed 
to increase the mass of bunches. The stimulating effect of the drugs was manifested to a greater extent in the variant of the experiment with Mival Agro (Fig. 2).

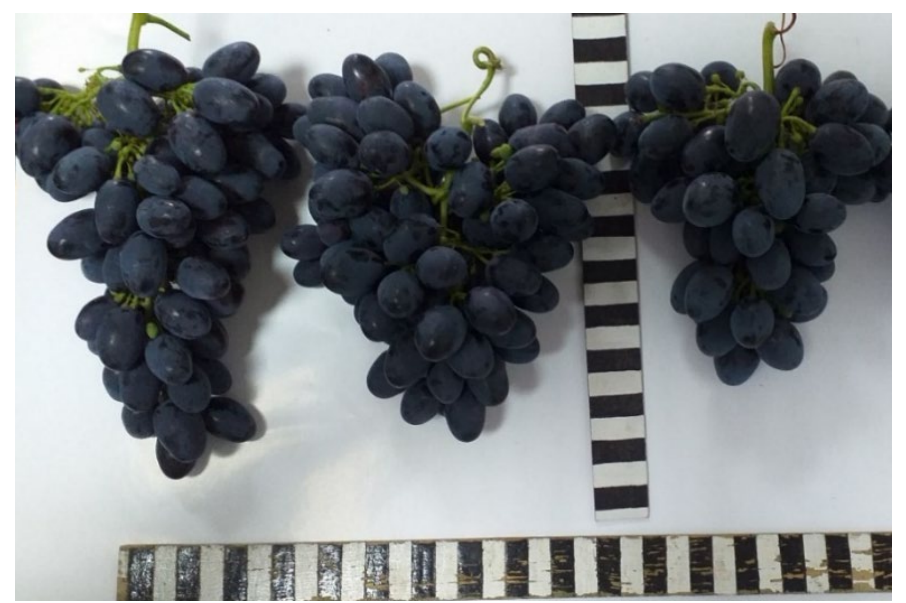

Fig. 2. The effect of plant growth regulators on the size of a bunch of grapes of the Kodrianka variety with the drugs 1) Zircon; 2) Mival Agro; 3) Control without treatment.

Treatment of experimental bushes with drugs contributed to a significant increase in productivity depending on the drug. The productivity from a bush of the Arkadia variety varied within the range of $3.18-5.43 \mathrm{~kg}$ (Fig. 3).

In the variant with the Zircon drug, the productivity of plants increased by $35.6 \%$ relative to the control value.

Productivity per one bush, $\mathrm{kg}$

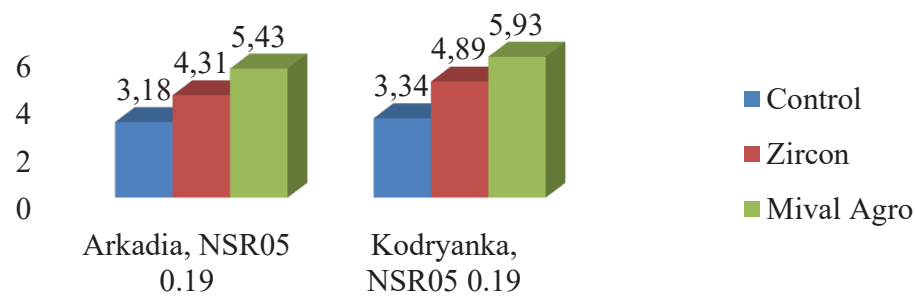

Fig. 3. Productivity of Arcadia and Codrianka varieties when using growth regulators.

Of the investigated variants of the experiment Mival-Agro was the most effective, the productivity from a bush of the Arkadia variety increased by $70.8 \%$.

The productivity from the Kodryanka variety bush varied within $3.34-5.93 \mathrm{~kg}$.

In the variant with the Zircon drug the productivity of plants of the Kodryanka variety was $4.89 \mathrm{~kg}$, the indicator increased by $46.4 \%$ relative to the variant without treatment.

Of the studied variants of the experiment, Mival-Agro was noted as the most effective, the average productivity of plants of the Kodryanka variety was $77.5 \%$ higher than the control value.

Productivity is the most important indicator of the biological and economic characteristics of the variety and depends on environmental and agricultural practices in viticulture.

The average yield of the Arkadia variety varied from $7.0-11.9 \mathrm{t} / \mathrm{ha}$.

In the variant with the Zircon drug the average yield increase was $35.7 \%$. 
Treatment of experimental bushes of the Arkadia variety with drug Mival - Agro contributed to the maximum yield of 11.9 tons per hectare, the increase in the experimental version was $70.0 \%$ (Table 3.).

Table 3. The effect of plant growth regulators on the yield of the Arkadia variety, $\mathrm{t} / \mathrm{ha}$.

\begin{tabular}{|c|c|c|c|}
\hline \multirow{2}{*}{ Experience options } & \multirow{2}{*}{$\mathrm{X}_{\mathrm{av}}, \mathrm{t} / \mathrm{ha}$} & \multicolumn{2}{|c|}{ Deviation from control } \\
\cline { 3 - 4 } & & $\mathrm{t}$ & $\%$ \\
\hline Control & 7.0 & - & - \\
\hline Zircon & 9.5 & 2.5 & 35,7 \\
\hline Mival-Agro & 11.9 & 4.9 & 70.0 \\
\hline NSR 05 & 0.18 & - & - \\
\hline
\end{tabular}

The average yield of the Kodryanka variety varied within 7.3-13.0 tons. In the variant with the Zircon drug, the average yield of this variety per hectare increased by $47.9 \%$ on average (Table 4).

Table 4. Influence of growth regulators on the yield of the Kodryanka variety, $\mathrm{t} /$ ha.

\begin{tabular}{|c|c|c|c|}
\hline \multirow{2}{*}{ Experience options } & \multirow{2}{*}{$\mathrm{X}_{\mathrm{av}}, \mathrm{t} / \mathrm{ha}$} & \multicolumn{2}{|c|}{ Deviation from control } \\
\cline { 3 - 4 } & & $\mathrm{t}$ & $\%$ \\
\hline Control & 7.3 & - & - \\
\hline Zircon & 10.8 & 3.5 & 47.9 \\
\hline Mival-Agro & 13.0 & 5.7 & 78.1 \\
\hline NSR 05 & 0.17 & - & - \\
\hline
\end{tabular}

The treatment of experimental bushes of the Kodryanka variety in the variant with the use of the Mival-Agro drug showed the maximum yield in comparison with the control variant increased by $78.1 \%$.

\section{Conclusions}

As a result of studies of the effect of plant growth regulators Mival-Agro and Zircon, it was found that the drugs contributed to an increase in the mass of the bunch, productivity from a bush and the yield of varieties Arkadia and Kodryanka. The stimulating effect of the drugs was noted to a greater extent in the variant of the Mival-Agro experiment.

\section{Acknowledgments}

The research was carried out within the framework of state assignment No. 0432-2021-0003. 


\section{Conflict of interests}

Not declared

\section{References}

1. A.A. Lukyanov, Scientific works of the SKFNT SVV, 22, 31-34 (2019)

2. L.P. Troshin, Ampelography and grape selection, 138 (Krasnodar: RIC "Free masters", 1999)

3. M.A. Tikhonova, E.V. Aminova, O.E. Merezhko, Russian grapes, 12, 18-23 (2020)

4. A.J. Winkler, A.M. Negrul, Viticulture in USA, 651 (M.: "Kolos", 1966)

5. A.M. Negrul, V.N. Chigrin, A.Ya. Kuzmin, Grape culture, 182 (Moscow: Selhozizdat, 1955)

6. F.I. Shatilov, Northern viticulture of Russia, 146 (Orenburg: OSU, 1998)

7. M.K. Uskov, S.V. Mikhailov, The influence of growth stimulants on the marketability of bunches of table grapes, Experimental and theoretical studies in modern science: collection of articles based on the materials of the $5^{\text {th }}$ international scientific and practical conference, 5 (5), 44-49 (Novosibirsk: SibAK, 2017)

8. G. Alleweldt, E. Dettweiler, The genetic resources of Vitis - Siebeldingen, 74 (FRG, 1994)

9. S.M. Zahedi, M. Karimi, J.A. Teixeira da Silva, Journal of the Science of Food and Agriculture, 100 (1), 25-31 (2020) doi: 10.1002 / jsfa.10004.

10. D. Wallschlager, M.V. Desai, R.D. Wilker, The role of humic substances in the aqueous mobilization of mercury from contaminated floodplain soils, water, air, and soil pollution, $90(3 / 4), 507-520$ (1996)

11. R.E. Kazakhmedov, Scientific works of SKFNTsSVV, Krasnodar: SKFNT SVV, 23, 211-215 (2019)

12. E.A. Ivanova, G.R. Mursalimova, M.A. Tikhonova, Bulletin of the Orenburg Scientific Center of the Ural Branch of the Russian Academy of Sciences, 4, 13 (2018)

13. T. Frioni, P. Sabbatini, S. Tombesi, et al., Scientia Horticulturae, 232, 97-106 (2018) https://doi.org/10.1016/j.scienta.2017.12.054

14. M.A. Tikhonova, R.R. Salimov, M.A. Panova, Bulletin of the Orenburg Scientific Center of the Ural Branch of the Russian Academy of Sciences, 4, 21 (2018)

15. G. Gutiérrez-Gamboa, G. Romanazzi, T. Garde-Cerdán, E.P. Pérez-Álvarez, Journal of the Science of Food and Agriculture, 99 (3), 1001-9 (2019) https://doi.org/10.1002/jsfa.9353

16. B.P. Pleshkov, Workshop on plant biochemistry, 256 (M.: "Kolos", 1976)

17. M.A. Lazarevsky, Study of grape varieties, 251 (Rostov-on-Don: Publishing house of the Russian State University, 1963)

18. Program and methodology for the variety study of fruit, berry and nut crops, 608 (Orel: VSRISPK, 1999)

19. B.A. Dospekhov, Field experiment technique, 352 (M.: Agropromizdat, 1985)

20. M.A. Pelyakh, Winegrower, 344 (Handbook, M.: Kolos, 1971) 